термінологію;

- складіть усне повідомлення на тему: «Моя майбутня професія», використовуючи професійну термінологію;

- у запропонованих текстах виправте терміни, вжиті в невластивому для них значенні;

- перекладіть запропоновані тексти зі спеціальності українською мовою, зверніть увагу на особливості перекладу стійких термінологічних сполук, які не мають дослівних українських відповідників російським варіантам.

Виконання таких видів робіт допоможе студентам уникнути калькування під час перекладу текстів фахового спрямування, зорієнтує щодо вживання нормативних форм термінів, фахових стійких терміносполучень, допоможе уміло й доречно використовувати найбільш уживані в певній сфері виробництва фахові терміни в певних робочих ситуаціях як цілісну комунікативну систему, а не як сукупність окремо взятих лексем, фразеологічних терміносполучень.

Отже, вивчення української фахової термінології як системи слугує основою для опанування майбутньої професії. Поєднання комунікативного підходу та професійного контексту - це запорука успішного засвоєння й подальшого активного використання базової наукової та професійної термінології. Створення методичних посібників 3 української мови за професійним спрямуванням, наповнених текстами, що несуть базові знання 3 обраного фаху та містять часто вживану термінологію зі спеціальності, створення перекладних словників фахових термінів, правильно дібрані вправи i завдання, спрямовані не тільки на переклад термінів, але й на активізацію вмінь говорити, слухати, активне використання термінів в усному та писемному українському фаховому мовленні, у різних навчальних ситуаціях допоможе зацікавити студентів їх майбутньою професією, прищепити любов до української мови та виховати національно свідомих, мовленнєво компетентних фахівців, які зможуть досягти особистісного й професійного рівня, визнання й реалізуватися в обраній професії.

\title{
Література
}

1. Борисюк I. Явище синонімії в термінології/ Іван Борисюк// Дивослово. 2008. - № 5. - С. 27-28. 2. Мацюк 3. Українська мова професійного спілкування: [навч. посіб.] / 3. Мацюк, Н. Станкевич. - К. : Каравела, 2005. - 352 с. 3. Овчаренко Н. Теоретичні передумови дослідження терміносистем / Наталія Овчаренко // Дивослово. 2013. - № 11. - С. 43-45. 4. Туровська Л. Галузеве термінознавство в Україні на початку XXI століття/Л. Туровська // Дивослово. - 2013. - № 11. - С. 38-41. 5. Лейчик В.О языковом субстрате термина / В. Лейчик// Вопросы языкознания. 1986. - № 5. - С. 87-97. 6. Панько Т.Українське термінознавство / Т. Панько, І. Кочан, Г. Мацюк. - Львів : Світ, 1994. - 216 с. 7. Флоренский П. Термин / П. Флоренский // Вопросы языкознания. - 1989. - № 1. - С. 121-133.

УДК 378.147

Анастасія Логвіненко

\section{ВИКОРИСТАННЯ ІНТЕРАКТИВНИХ МЕТОДІВ НАВЧАННЯ В ПІДГОТОВЦІ МАЙБУТНІХ УЧИТЕЛІВ ІНОЗЕМНОЇ МОВИ ДО ТОЛЕРАНТНОЇ КОМУНІКАТИВНОЇ ДІЯЛЬНОСТІ}

Логвіненко А. Ю. Використання інтерактивних методів навчання в підготовці майбутніх учителів іноземної мови до толерантної комунікативної діяльності.

Статтю присвячено розгляду сутності інтерактивних методів навчання та їх ролі у процесі підготовки майбутніх учителів іноземної мови до толерантної комунікативної діяльності. Наведено приклади інтерактивних форм, що сприяють розвитку комунікативних, творчих здібностей, толерантного ставлення до 
представників інших народів під час навчання іноземної мови.

Ключові слова: інтерактивні методи навчання, майбутні вчителі іноземної мови, комунікативні здібності, толерантність.

Логвиненко А. Ю. Использование интерактивных методов обучения в подготовке будущих учителей иностранного языка к толерантной коммуникативной деятельности.

Статья посвящена рассмотрению сущности интерактивных методов обучения и их роли в процессе подготовки будущих учителей иностранного языка к толерантной коммуникативной деятельности. Приведены примеры интерактивных форм, способствующих развитию коммуникативных, творческих способностей, толерантного отношения к представителям других народов во время обучения английскому языку.

Ключевые слова: интерактивные методы обучения, будущие учителя иностранного языка, коммуникативные способности, толерантность.

Logvinenko A.Y. Using interactive teaching methods to prepare future teachers of foreign language tolerant communication activities.

The article is devoted to consideration of interactive methods of teaching and their role to the tolerant communicative activity in the process of future foreign language teachers' training. The examples of interactive forms that favor development of communicative and creative skills, tolerant attitude to representatives of other nations while teaching English are shown.

Key words: interactive methods of teaching, future teachers of foreign languages, communicative skills, tolerance.

Процеси інтеграції України до європейськогота світового товариства, нові соціально-економічні умови розвитку суспільства висувають все вищі вимоги до підготовки фахівців у галузі мовної освіти. Нове соціальне замовлення сучасного суспільства полягає не лише в навчанні іноземної мови як засобу спілкування, а й у формуванні багатомовної особистості, яка має поєднувати в собі цінності рідної та іншомовної культур і готова до міжкультурної комунікації [1]. Зазначене передбачає внесення сутнісних змін у навчально-виховний процес за допомогою нових технологій, що грунтуються на застосуванні інтерактивних методів навчання. Специфіка навчання за допомогою активних методів навчання полягає в тому, що мислення і поведінка студентів примусово активізуються, спілкування студентів 3 викладачем і один 3 одним відбувається на високому рівні мотивації, емоційності і творчості, формування у студентів педагогічних умінь відбувається в обмежені строки. Активні методи навчання підтримують у студентів творче напруження, діловий азарт, позитивне збудження, емоційність, зацікавленість. Натомість проблема використання інтерактивних методів у процесі підготовки майбутніх учителів іноземної мови до толерантної комунікативної діяльності в сучасній педагогічній літературі висвітлена недостатньо.

Різні аспекти професійної підготовки вчителя перебувають у колі наукових досліджень О. Абдулліної, А. Алексюка, І. Богданової, О. Дубасенюк, І. Зязюна, О. Мороз, А. Мудрика, С. Сисоєвої, В. Сластьоніна, Г. Троцко та ін. Професійна підготовка майбутнього вчителя іноземних мов розглядається у працях І. Зимньої, Ю. Пассова, С. Ніколаєвої, А. Бердичевського та ін. Застосуванню інтерактивних технологій у навчальному процесі середньої та вищої школи присвячені дослідження О. Глотова, С. Гончарова, Л. Пироженко, О. Пометун, Г. П’ятакової.

До проблеми активізації професійної підготовки майбутніх учителів звертаються українські науковці (І. Бех, А. Богуш, М. Свтух, І. Зязюн, М. Нечаєв, Н. Ничкало, 78

Педагогіка вищої та середної школи. - 2014. - Вип. 41 
О. Сухомлинська та ін.), які наголошують на необхідності перебудови традиційних способів організації навчально-виховного процесу вищої школи i пропонують застосування активних методів навчання, що передбачають створення ситуацій, що максимально наближені до майбутньої професійної діяльності. Досліджуючи активність студентів у навчальному процесі, К. Абульханова, Н. Васіна, Л. Лаптєва, В. Сластьонін розглядають ї як інтенсивну діяльність і практичну підготовку у процесі навчання й формування знань та навичок, уміння застосовувати їх у конкретних ситуаціях, тобто активність у навчанні $є$ умовою свідомого засвоєння знань, умінь та навичок [6, с. 173-178].

Meта статmi - розглянути сутність інтерактивних методів навчання та їх роль у процесі підготовки майбутніх учителів іноземної мови до толерантної комунікативної діяльності.

Сутність інтерактивного навчання полягає в тому, що навчальний процес відбувається виключно шляхом постійної активної взаємодії всіх студентів [7, с. 13]. Його основними рисами є: двобічний характер; спільна діяльність викладача і студента; керівництво процесу викладачем; спеціальна організація та різноманітність форм; інформаційна прогалина; цілісність та єдність; мотивація та зв'язок з реальним життям; виховання та розвиток особистості студентів одночасно з процесом засвоєння нових знань.

Рольові ігри, що використовуються на заняттях, наголошує М. Свтух[3, с. 172], розвивають не тільки знання в майбутніх фахівців, активізують і загострюють сприймання матеріалу, надають змогу програвати конкретні педагогічні ситуації, формують уміння встановлювати контакти, проявляти ставлення до вихованців, але й дозволяють вивчати й узагальнювати досягнення педагогічної науки та шкільної практики, поновлювати, поглиблювати зміст і технології професійного навчання студентів, спрямованого на формування їхньої толерантності.

У формуванні особистості майбутніх фахівців у навчально-виховному процесі, на думку Т. Вахрушевої [2], методи інтерактивного навчання відіграють особливу роль, оскільки саме вони активізують самостійність думок студентів, залучають їх до роботи 3 великим обсягом інформації, формують систему ставлень, створюють атмосферу порозуміння і співпереживання, роблять студентів справжніми суб'єктами навчання. Розвиток й упровадження зазначених методів навчання зумовлений тим, продовжує науковець, що перед викладачами ставляться завдання не лише засвоєння студентами знань і формування професійних умінь та навичок, а й розвитку творчих $\mathrm{i}$ комунікативних здібностей особистості, формування особистісного підходу до розв'язання проблеми. Саме у процесі такого навчання розвиваються самооцінка, самоповага, толерантність, самостійність, відповідальність, прийняття точки зору інших, вміння дискутувати та відстоювати свої переконання.

На важливості використання в навчально-виховному процесі інтерактивних технологій наголошує й Т. Хлєбнікова [8]. На думку науковця, вони дозволяють діагностувати стан колективу слухачів; визначати стан психологічного клімату; здійснювати прямий i зворотний зв'язок; здійснювати навчальну, розвивальну i виховну функції; створювати умови для творчої діяльності; учитися самостійності, відповідальності, розумному індивідуалізму; визначати пріоритетні напрями діяльності; виробляти вміння приймати управлінські рішення; учитися формулювати думки; уживатися в різні ситуації і рольові позиції; учитися працювати в малих групах і з малою групою; учитися аналізувати i знаходити вихід із проблемних ситуацій; учитися експромту в умовах дефіциту часу й інформації. 
Залучення студентів до рольових та ділових ігор, імітаційне моделювання педагогічних ситуацій, наголошує М. Пащенко [5], надають змогу шляхом активної взаємодії між студентами приймати рішення, засвоювати конкретні професійні вміння. Крім того, продовжує авторка, ділова гра сприяє створенню невимушеної, неформальної обстановки на заняттях, відвертих, доброзичливих і довірливих стосунків між студентами і викладачами, вияву толерантності.

Під час колективної ігрової діяльності, у процесі спілкування, зазначають науковці (А. Буданов, І. Карпюк, А. Куракін, В. Максакова, О. Мудрик, Л. Новикова, С. Поляков та ін.), у майбутніх учителів виробляються навички поведінки в колективі, уміння працювати 3 людьми, розуміти їхню психологію, засвоювати той чи той стиль керівництва. При цьому, зауважує М. Бондаренко [1], уміння колективної діяльності дають можливість студентам правильно використовувати набуті знання й навички, творчо застосовувати засоби професійної педагогічної діяльності під час виконання завдань у різноманітних умовах.

Під час підготовки майбутніх учителів до толерантної комунікативної діяльності на заняттях 3 англійської мови, нанашу думку, доцільно використовувати такі інтерактивні форми мовленнєвого спілкування: семінари, диспути, обговорення проблемних завдань, рольові та ділові ігри. Зокрема, усвідомленню студентами значущості толерантності у професійній діяльності та виробленню відповідних якостей сприятиме проведення занять за такими темами, як-от: «Subculture presentation», «Scum of society: problems of social attitude and government policy», «Ethnos», «Nations», «International relations», «Features of tolerant personality» тощо.

Під час практичних занять можна також проводити круглі столи за такими темами: «Portrait of Englishman of 21 st century», «We are in global community», «Planet without wars», «Tolerance or conformism», «Stereotypes preventing to livet warst personalutyt policyve skills, tolerant attitude to representativenguage techers'», «To be unlike and live in harmony», "Youth culture, music, fashion».

Уважаємо, що проведення таких занять сприятимуть усвідомленню студентами цінностей ненасильства, виробленню вмінь обирати правильну поведінку в соціальних конфліктах і знаходити конструктивні рішення, формуватимуть у них почуття справедливості. Крім цього, під час занять здійснюється розвиток критичного мислення студентів, навичок навчальної самоорганізації, групової роботи, умінь вести діалог і аргументувати свою думку, продуктивно опонувати й адекватно, по достоїнству, оцінювати інші позиції [5].

Під час проведення занять 3 використанням інтерактивних методів навчання студенти набувають умінь дивитися на довколишній світ очима інших людей, розуміючи, що вони можуть сприймати й оцінювати ті самі факти, вчинки, події інакше; толерантно ставитися до представників інших національностей, щоб мова дійсно стала засобом спілкування та взаємодопомоги між людьми, оскільки саме від уміння ефективно спілкуватися багато в чому залежить наше життя. Толерантність допоможе студентам знайти спільну мову як із друзями, батьками, ровесниками, викладачами, так і представниками інших культур.

Завданням викладача під час інтерактивного навчання $є$ залучення майбутніх учителів іноземної мови до обговорення запропонованих тем, проблем; уважне слухання студентів і навчання їх слухати один одного; природна поведінка, виправлення допущених помилок у формі підказки правильної відповіді (мимохідь). Уважаємо, що за умови, якщо викладачу вдасться успішно розв'язати всі ці завдання, то кожне заняття буде уроком, що формує навички комунікативної толерантності. 
Отже, застосування інтерактивних методів навчання на заняттях 3 іноземної мови можна розглядати як педагогічну умову, що сприятиме набуттю майбутніми вчителями необхідних умінь та навичок комунікативної толерантності. 3 огляду на зазначене перспективою подальшого дослідження $\epsilon$ розроблення змісту позааудиторних інтерактивних занять задля підготовки студентів до формування толерантності в учнів основної школи в майбутній професійній діяльності.

\section{Література}

1. Бондаренко М. П. Організація і виховання студентського колективу / М. П. Бондаренко. - К. : Вища школа, 1979. - 69 с. 2. Вахрушева Т. Ю. Теоретичні аспекти активних методів навчання [Електронний ресурс]. - Режим доступу: http://www.nbuv.gov.ua/portal/Soc_Gum/PPMB/texts/2008-03/08vtyaml.pd

3. Свтух М. Б. Сучасні тенденції професійної підготовки вчителя / М. Б. Свтух // Психолого-педагогічні основи гуманізації навчально-виховного процесу в школі та вузі: зб. наук. праць. - Рівне : Волинські обереги, 2002. - Вип. 3. - С. 170-175. 4. Исмагилова 3. А. Воспитание толерантности у студентов педагогического вуза в процессе изучения иностранного язика: автореф. дис. на соискание ученой степени канд. пед. наук: специальность 13.00.01 «Общая педагогика, история педагогики и образования» / 3. А. Исмагилова. - Казань, 2007. - 20 с. 5. Пащенко М. І. Активні методи навчання у підготовці майбутніх учителів[Електронний ресурс].- Режим доступу: http://eprints.zu.ua/2142/1/3.pdf.6. Педагогика и психология высшей школы / под ред. С. И. Самыгина. - Ростов-н/Д. : Феникс, 1998. - 526 с. 7. Пометун О. Енциклопедія інтерактивного навчання/ О. Пометун. - К. : АСК, 2007.- 144 с. 8. Хлєбнікова Т. М. Ділова гра як метод активного навчання педагога:[навч.-метод. посіб. для викл., директорів шкіл, керівн. РУО]/ Т. М. Хлєбнікова. - Х. : ВГ «Основа», 2003. - 80 с.

УДК 37.012:[378:37.011.3]

Світлана Мантуленко

\section{СИСТЕМНИЙ МОНІТОРИНГ У ФОРМУВАННІ ГОТОВНОСТІ МАЙБУТНІХ УЧИТЕЛІВ ГЕОГРАФЇ̈ ДО ПРОФІЛЬНОГО НАВЧАННЯ СТАРШОКЛАСНИКІВ ЯК НЕОБХІДНА УМОВА ЕФЕКТИВНОСТІ ЦЬОГО ПРОЦЕСУ}

Мантуленко С. В. Системний моніторинг у формуванні готовності майбутніх учителів географії до профільного навчання старшокласників як необхідна умова ефективності цього процесу.

У статті здійснено аналіз наукових підходів до визначення сутності проблеми моніторингу в освіті, теоретично обгрунтовано механізм здійснення системного моніторингу у формуванні готовності майбутніх учителів географії до профільного навчання старшокласників як важливої умови ефективності цього процесу.

Ключові слова:моніторинг, освітній моніторинг, моніторинг професійного розвитку, системний моніторинг, контроль.

Мантуленко С. В. Системный мониторинг в формировании готовности будущих учителей географии к профильному обучению старшеклассников как необходимое условие эффективности этого процесса.

В статье осуществлён анализ научных подходов к определению сущности проблемы мониторинга в образовании, теоретически обосновано осуществление системного мониторинга в формировании готовности будущих учителей географии к профильному обучению старшеклассников как необходимое условие эффективности 